\title{
Diversifikasi produk melalui pemanfaatan tepung umbi- umbian lokal sebagai pengganti terigu pada UKM bakery di Kota Binjai
}

\author{
Elisa Julianti (DiD *1, Ridwansyah"1, Terip Karo-Karo', Halimatuddahliana ${ }^{2}$ \\ ${ }^{1}$ Program Studi IImu dan Teknologi Pangan, Fakultas Pertanian, Universitas \\ Sumatera Utara \\ 2 Departemen Teknik Kimia, Fakultas Teknik, Universitas Sumatera Utara \\ *elisa1@usu.ac.id
}

\begin{abstract}
The bakery industry is one of the food industries that continues to increase along with the increase in income and changes in people's lifestyles. Increasing the number of bakery industries has an impact on the increasing demand for wheat flour, which in turn can threaten national food security. Faidah Catering Service and Baraqah Q Snack, Cake and Cookies are SME partners engaged in bakery industry in Binjai City. Based on the situation analysis, the problems of both SMEs are low production capacity and competition in the marketing. The use of wheat flour as the raw material makes their products become same as the products produced by other SMEs. The simple processing equipment causes a low production capacity. The proposed problem-solving method for SME partners is product diversification through the use of local tubers in the form of cassava flour and sweet potato flour as raw material. Increased production capacity is carried out by giving and training the use of production equipment in the form of dough mixers and oven grills with large capacity. The results of the activity indicate that the diversification of cake products and cookies using non-flour flour raw materials can be accepted by consumers and increase marketing.
\end{abstract}

\begin{abstract}
Abstrak Industri bakery merupakan salah satu industri pangan yang terus mengalami peningkatan seiring dengan meningkatnya pendapatan serta terjadinya perubahan gaya hidup masyarakat. Peningkatan jumlah usaha bakery berdampak pada semakin tingginya kebutuhan akan terigu sehingga dapat mengancam ketahanan pangan nasional. Faidah Catering Service serta Baraqah Q Snack, Cake dan Cookies merupakan Mitra UKM yang bergerak di bidang pengolahan produk bakery di Kota Binjai. Berdasarkan analisis situasi yang menjadi permasalahan kedua UKM ini adalah rendahnya kapasitas produksi dan persaingan dalam pemasaran produk. Penggunaan bahan baku terigu dalam pengolahan produk menjadikan produk yang dihasilkan sama dengan produk bakery oleh UKM lain. Penggunaan fasilitas produksi yang sederhana menyebabkan kapasitas produksi rendah. Metode penyelesaian masalah yang diusulkan kepada Mitra UKM adalah diversifikasi produk penggunaan bahan baku tepung umbi-umbian local, berupa tepung ubi kayu dan ubi jalar. Peningkatan kapasitas produksi dilakukan dengan pelatihan penggunaan peralatan produksi berupa mixer adonan dan oven pemanggang kapasitas besar. Hasilnya diversifikasi produk cake dan cookies menggunakan bahan baku tepung non terigu bisa diterima oleh konsumen dan meningkatkan pemasaran.
\end{abstract}

Keywords: bakery; diversification; tuber flour; wheat flour; SME

\section{ठ OPEN ACCESS}

Citation: Julianti, E., Ridwansyah, T. Karo-Karo, dan Halimatuddahliana. 2018. Diversifikasi produk melalui pemanfaatan tepung umbiumbian lokal sebagai pengganti terigu pada UKM produk bakery di Kota Binjai. Riau Journal of Empowerment 1(2): 75-83

https://doi.org/10.31258/raje.1.2.10

Received: 2018-11-08, Revised: 2018-12-17, Accepted: 2018-12-20

Funding: Kegiatan pengabdian ini didanai oleh Lembaga Pengabdian Pada Masyarakat Universitas Sumatera Utara melalui Skim Pengabdian Mono Tahun BPPTN USU Tahun 2018

Language: Bahasa Indonesia (id)

C 2018 Julianti et al. The article by Author(s) is licensed under a Creative Commons Attribution 4.0 International License. This license permits unrestricted use, distribution, and reproduction in any medium, provided the original author and source are credited. 


\section{PENDAHULUAN}

Usaha Kecil Menengah (UKM) merupakan salah satu motor penggerak perekonomian Indonesia karena telah terbukti mampu bertahan pada masa krisis ekonomi dan menjadi dinamisator pertumbuhan ekonomi pasca krisis ekonomi. Sektor industri pengolahan pangan merupakan salah satu sektor yang banyak diusahakan UKM, dimana pada 2007 menempati urutan ketiga dengan persentasi sebesar 6,49 persen. Industri pangan mempunyai peranan penting dalam pemenuhan dan penganekaragaman pangan. Produk-produk bakery seperi cake, cookies, dan kue-kue (patiseri) merupakan salah satu alternatif makanan jadi yang cukup diminati masyarakat karena tersedia dalam aneka pilihan rasa, praktis penyajiannya, dan dapat dinikmati mulai anak-anak sampai orang tua. Oleh karena itu, konsumsi terhadap produk bakery juga mengalami peningkatan setiap tahunnya. Kondisi ini dapat menjadi peluang pasar yang potensial bagi industri bakery yang ingin mengembangkan usahanya.

Produk bakery seperti cake, cookies, dan kue-kue umumnya menggunakan terigu sebagai bahan baku. Terigu adalah bahan baku pangan yang berasal dari biji gandum dan hingga saat ini masih diimpor. Berdasarkan data Badan Pusat Statistik (2012), impor biji gandum pada tahun 2011 mencapai 4,8 juta ton dengan nilai 1,4 Milliar US\$, sedangkan impor terigu mencapai 775 ribu ton. Permintaan terigu diperkirakan akan terus meningkat menjadi 10 juta ton per tahun menurut Asosiasi Produsen Tepung Terigu Indonesia (2012). Peningkatan kebutuhan terigu ini, akan mengancam ketahanan dan kedaulatan pangan nasional.

Terigu mengandung komponen gluten yang membedakannya dari tepung-tepungan lain. Gluten adalah protein yang bersifat lengket dan elastis. Dalam Pembuatan roti, gluten bermanfaat untuk mengikat dan membuat adonan menjadi elastis sehingga mudah dibentuk. Karakteristik gluten yang demikian menyebabkan terigu menjadi bahan utama dalam pembuatan roti dan mi. Tetapi adanya kandungan gluten pada terigu, membuat sebagian orang seperti penderita autis dan penyakit seliak (celiac disease) menjadi alergi jika mengonsumsi bahan pangan yang mengandung terigu. Penderita penyakit seliak adalah orang yang sepanjang hidupnya tidak toleran terhadap kandungan prolamin pada gandum (gliadin), rye (secalin) dan barley (hordein) (Nehra et al., 2013). Oleh karena itu, untuk penderita autis dan penyakit seliak dibutuhkan produk pangan yang tidak mengandung gluten. Peningkatan pendapatan dan perubahan gaya hidup, menyebabkan masyarakat mulai mencari bahan pangan yang aman dan sehat seperti makanan rendah kolesterol, tidak mengandung alergen, murah, masa simpannya panjang dan tidak memerlukan refrigerasi (Lin et al., 2003; Swaran et al., 2003).

Kota Binjai juga tidak terlepas dari perkembangan usaha bakery, dimana jumlah usaha bakery di Kota Binjai semakin meningkat setiap tahunnya. Bertambahnya jumlah produsen roti akan berimplikasi terhadap tingkat persaingan yang semakin tinggi diantara perusahaan roti. Faidah Catering Service dan Baraqah Q Snack, Cake dan Cookies merupakan UKM yang bergerak di bidang pengolahan produk bakery di Kota Binjai. Tingginya persaingan ini menjadi salah satu faktor bagi Faidah Catering Service dan Baraqah Q Snack, Cake dan Cookies untuk melakukan pengembangan usaha.

Faidah Catering Service merupakan salah satu UKM yang bergerak dalam bidang usaha katering dan kue-kue kotak (box) untuk berbagai kegiatan dan acara di Kota Binjai. UKM ini berlokasi di Jalan Nenas II Kelurahan Sukaramai Kecamatan Binjai Barat Kota Binjai. Pendiri usaha ini Richi Tioman Sitorus, ST memulai usahanya pada tahun 2012. Saat ini Faidah Catering Service memiliki omzet mencapai Rp.6.000.000,-/bulan dengan keuntungan bersih mencapai Rp.3.000.000,-/bulan. Faidah Catering Service tidak hanya melayani penjualan nasi kotak, tetapi juga kue-kue kotak. Jenis kue yang biasa diproduksi adalah cake, cookies, produk patiseri seperti risol, donut, dan kue-kue basah lainnya. UKM ini menggunakan terigu sebagai bahan bakunya. Proses produksi masih dilakukan dengan cara sederhana menggunakan alat yang juga sederhana. Pertemuan masyarakat yang dilakukan oleh Walikota Binjai, organisasi kemasyarakatan, maupun warga di sekitar lokasi dimana UKM ini berada, sering memesan katering dan kue kotak dari Faidah Catering Service.

Baraqah Q Snack, Cake dan Cookies adalah UKM yang juga bergerak di bidang pengolahan produk bakery yang didirikan pada tahun 2015 oleh Arfina Muharny, SE. Produk 
yang dihasilkan adalah snack, cake, dan cookies yang juga menggunakan terigu sebagai bahan bakunya. UKM ini sebenarnya sudah menggunakan ubi kayu, ubi jalar, maupun labu sebagai bahan bakunya, tetapi masih dalam bentuk segar, sehingga tidak bisa disimpan dalam waktu yang lama. Kapasitas produksi masih sangat rendah, karena hanya dipasarkan di warung di sekitar rumah, dan pemasaran melalui pesanan baik pemesanan langsung maupun pemesanan melalui media sosial yaitu melalui Facebook. Omzet UKM ini perbulan masih sangat kecil yaitu sekitar Rp.3.000.000,- dengan keuntungan sekitar Rp.2.000.000,-.

\section{MASALAH}

UKM Faidah Catering Service dan Baraqah Q Snack, Cake dan Cookies, memiliki peluang usaha yang sangat baik dan potensi untuk berkembang. Permasalahan kedua UKM adalah peralatan yang digunakan masih sangat sederhana dan belum memenuhi persyaratan untuk pengolahan yang sesuai standar, manajemen dalam pengelolaan belum baik, pemasaran masih mengandalkan pembeli yang datang ke rumah dan kemasan yang sederhana. Akibatnya produksinya tidak maksimal dan jangkauan pemasaran rendah. Penggunaan bahan baku terigu dalam pengolahan produk menjadikan produk yang dihasilkan menjadi sama dengan produk bakery yang dihasilkan oleh UKM lainnya sehingga persaingan menjadi semakin ketat.

Oleh karena itu, dibutuhkan perbaikan proses dan inovasi pengolahan produk bakery antara lain diversifikasi bahan baku dari terigu menjadi bahan baku tepung non terigu seperti tepung ubi kayu dan tepung ubi jalar, mengganti peralatan yang digunakan serta membuat variasi pengolahan produk bakery. Penggunaan tepung non terigu yang bebas gluten menjadi alternatif pasar bagi kedua UKM, karena produk yang dihasilkan dapat dipasarkan untuk masyarakat yang melakukan diet gluten maupun masyarakat penderita diabetes, karena tepung ubi kayu dan tepung ubi jalar memiliki indeks glikemik yang rendah sehingga baik untuk penderita diabetes. Hal ini juga memperhatikan kondisi di masyarakat dimana terjadi peningkatan penderita diabetes dan anak autis.

\section{METODE}

Metode yang digunakan dalam pelaksanaan kegiatan pengabdian pada masyarakat ini adalah:

a. Ceramah dan diskusi dilakukan saat memberikan materi baik usaha diversifikasi produk maupun perbaikan proses pengolahan produk bakery. Hal ini dilakukan untuk memberikan bekal pengetahuan dan wawasan untuk meningkatkan pengetahuan mereka. Ceramah dilakukan dengan tanya jawab dan diskusi sehingga diketahui tingkat pemahaman sasaran terhadap materi yang diberikan.

b. Penyerahan peralatan pengolahan produk bakery untuk dapat meningkatkan kapasitas produksi.

c. Praktek penggunaan peralatan yang baru sesuai kebutuhan untuk memperbaiki permasalahan yang sudah dijelaskan sebelumnya. Setelah mendapatkan pengetahuan maka mitra UKM perlu diberi praktek untuk meningkatkan keterampilan dan membuktikan hal-hal yang sudah disampaikan oleh pemateri. Diharapkan dengan adanya praktek akan mampu meningkatkan keterampilan secara nyata.

d. Peningkatan pemasaran produk melalui diversifikasi produk dan peningkatan kapasitas produksi. Diversifikasi produk dilakukan melalui penggunaan tepung umbi-umbian yaitu tepung ubi jalar dan mocaf sebagai pengganti terigu dalam pembuatan produk bakery yaitu cake, roti, cookies dan kue-kue basah. Peningkatan kapasitas produksi dilakukan melalui pemberian peralatan baru dengan kapasitas yang lebih tinggi sehingga mempercepat proses produksi.

e. Pendampingan dan monitoring. Dilakukan pendampingan dan monitoring untuk mengetahui sejauh mana mitra telah melakukan usaha dan kendala yang dihadapi agar mendapat penyelesaian dengan baik.

f. Evaluasi, dilakukan untuk mengetahui tingkat keberhasilan program dengan cara penilaian melalui wawancara dan pemantauan. 


\section{PEMBAHASAN}

\section{Tahapan atau langkah-langkah dalam melaksanakan solusi dari permasalahan mitra}

Tahapan kegiatan terdiri dari 3 tahap, yang merupakan tahapan dalam mengatasi permasalahan atau solusi terhadap permasalahan yang dihadapi mitra UKM yaitu permasalahan dalam aspek produksi, aspek manajemen dan aspek pemasaran.

\section{Tahap 1. Solusi permasalahan dalam aspek produksi}

Pengolahan produk bakeri di UKM Faidah Catering Service serta UKM Barokah Q Snack, Cake dan Cookies masih menggunakan menggunakan peralatan yang sederhana sehingga kapasitas produksi rendah. Masalah lain adalah bahan baku yang masih sama dengan produk bakery lainnya yaitu terigu sehingga persaingan usaha menjadi sangat ketat. Metode untuk menyelesaikan permasalahan pada bidang produksi yaitu memberikan bantuan berupa mixer pengadon dengan kapasitas $5 \mathrm{~kg} /$ produksi serta oven pemanggang yang besar dengan kapasitas $20 \mathrm{~kg} / \mathrm{jam}$. Alat lain yang diberikan adalah sealer pengemas yang digunakan untuk membantu UKM dalam mengemas produknya sehingga menjadi lebih menarik. Salah satu upaya untuk meningkatkan kapasitas produksi dan produktivitas usaha adalah melalui perbaikan atau pengembangan peralatan pengolahan. Pristiana et al. (2015) mengatasi permasalahan dalam kapasitas produksi pada UKM yang memproduksi bakpia di Gempol Pasuruan Jawa Timur melalui pemberian peralatan pengolahan berupa mixer pengaduk adonan, sehingga waktu proses pengolahan menjadi lebih singkat.

Spesifikasi alat produksi yang diberikan dapat dilihat pada Tabel 1. Kegiatan serah terima alat produksi kepada kedua UKM dapat dilihat pada Gambar 1. Tim kegiatan pengabdian juga melakukan pelatihan penggunaan peralatan produksi yang diserahkan (Gambar 2). Mitra telah menggunakan alat produksi yang diserahkan, dan telah merasakan manfaatnya, yaitu meningkatnya kapasitas produksi, terutama pada saat Hari Raya Lebaran, dimana permintaan akan produk cookies dan cakes meningkat.

Tabel 1. Spesifikasi alat produksi yang diserahkan kepada UKM mitra

\begin{tabular}{ll}
\hline \multicolumn{1}{c}{ Nama Alat } & \multicolumn{1}{c}{ Spesifikasi } \\
\hline $\begin{array}{l}\text { Oven Gas } \\
\text { Baking AKS- }\end{array}$ & $\begin{array}{l}\text { Power: } 80 \text {-watt, } 220 \mathrm{~V}, 50 \mathrm{~Hz} \\
\text { Jumlah Tray: } 2 \\
\text { Tekanan: } 2800 \mathrm{~Pa} \\
\text { Laju konsumsi Gas: } 30 \mathrm{MJ} / \mathrm{jam} \\
\text { Kapasitas Produksi: } 10 \mathrm{~kg} / \mathrm{jam} \\
\text { Dimensi Eksternal: } 160 \mathrm{x} 90 \mathrm{x} 65 \mathrm{~cm} \\
\text { Berat: } 100 \mathrm{~kg}\end{array}$ \\
& Kapasitas: $7 \mathrm{~L}$ \\
High Electric & Voltase: $220 \mathrm{~V} / 50 \mathrm{~Hz}$ \\
Food Mixer & Power: $300-400 \mathrm{Watt}$ \\
Machine AKS- & Dimensi: $500 \mathrm{x} 260 \mathrm{x} 460 \mathrm{~mm}$ \\
LH20HS & Mixing Limited: $0,5-0,8 \mathrm{~kg} / \mathrm{time}$ \\
& \\
&
\end{tabular}




\begin{tabular}{ll}
\hline Nama Alat & \multicolumn{1}{c}{ Spesifikasi } \\
\hline Cup Sealer & Merk: Double Thunders \\
Type: DT 8 S & Voltase: $220 \mathrm{~V} / 50 \mathrm{~Hz}$ \\
Daya Listrik: $300 \mathrm{Watt}$ \\
Kapasitas: 400 cup/jam
\end{tabular}
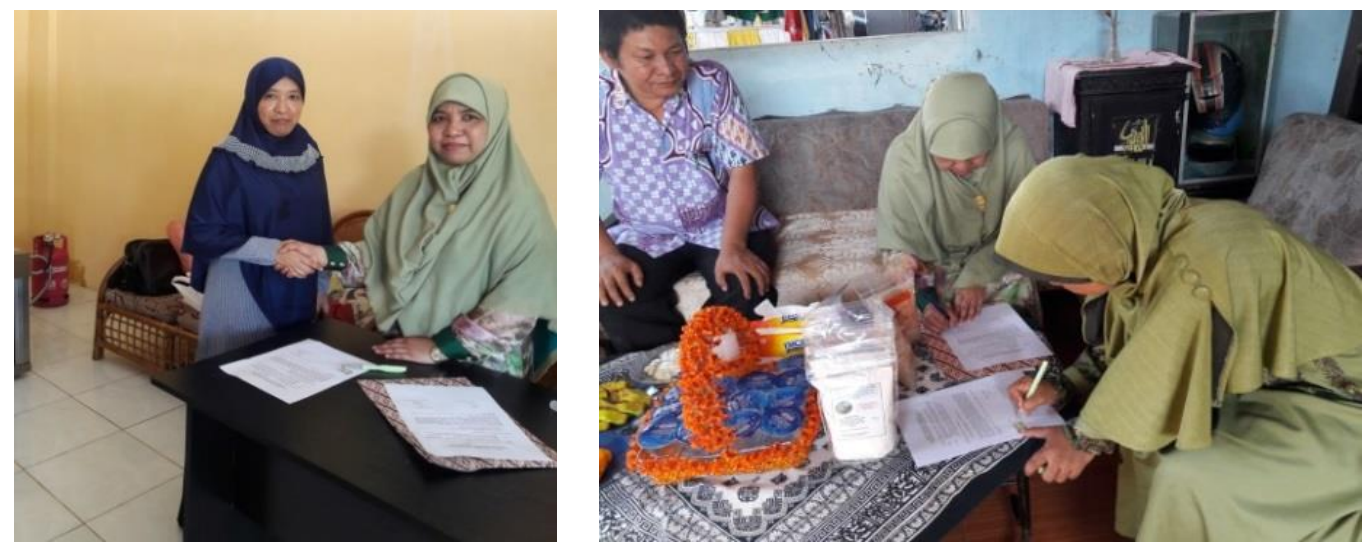

Gambar 1. Kegiatan serah terima alat produksi kepada UKM Mitra

\section{Tahap 2. Solusi permasalahan dalam aspek manajemen}

Hubeis (2004) menyatakan bahwa kelemahan utama UKM secara umum adalah lemahnya kemampuan manajerial meliputi perencanaan, pengorganisasian, pemasaran, maupun akuntansi. Secara umum kondisi manajemen usaha yang terdapat pada UKM Mitra terdiri dari 4 aspek, yaitu: 1) pengelolaan keuangan usaha yang masih sederhana dan belum mampu memisahkan antara keuangan usaha dengan keuangan pribadi; 2) produksi/operasional yang meliputi kekurangan pengetahuan di bidang teknologi dan kurangnya kreativitas untuk 
menciptakan produk baru; 3) pemasaran dan lingkup pemasaran yang terbatas serta kemampuan daya beli masyarakat sekitar yang rendah, serta 4) aspek sumberdaya manusia yang memiliki pengetahuan tentang pengembangan usaha yang masih kurang.
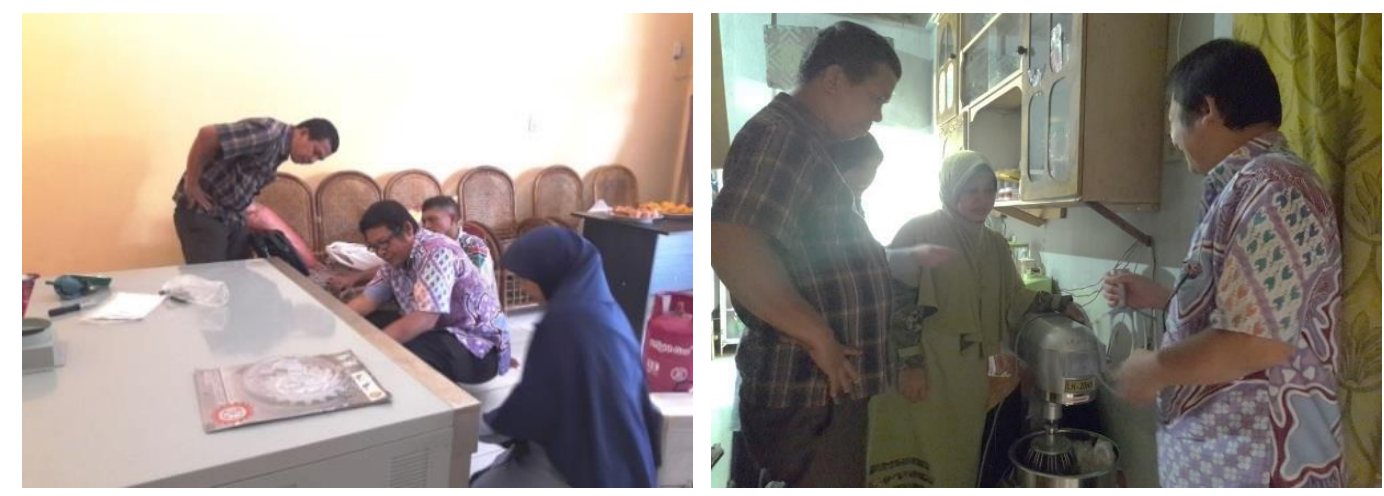

Gambar 2. Pelatihan penggunaan alat produksi di UKM Mitra

Kurangnya pengetahuan mitra meliputi pengetahuan tentang perizinan seperti ijin PIRT (Pangan Industri Rumah tangga) dari dinas kesehatan dan sertifikasi halal. Oleh karena itu permasalahan ini diselesaikan dengan cara memberi penyuluhan dan pelatihan mengenai manajemen usaha dan keuangan, bagaimana cara mendapatkan perijinan, serta cara mendapatkan PIRT agar usahanya lebih berkembang. Dalam meningkatkan usaha juga diberikan pengetahuan tentang diversifikasi usaha, proses pengolahan, penangan bahan baku, standar mutu, teknologi pengolahan, pengemasan dan pemasaran.

\section{Tahap 3. Solusi permasalahan dalam bidang pemasaran}

Daur produk di industri oleh Kottler dan Keller (2009) dikelompokkan menjadi 4 tahapan yaitu pengenalan, pertumbuhan, kedewasaan dan penurunan. Pada tahap penurunan terjadi penurunan penjualan secara cepat dikarenakan perubahan selera konsumen yang dapat disebabkan adanya produk-produk baru sehingga dapat menyebakan perusahaan akan mati dan mengundurkan diri. Oleh karena itu sebelum sampai pada tahap penurunan, maka perlu dilakukan perubahan strategi oleh perusahaan terkait dengan produk, yaitu melalui diversifikasi produk. Berdasarkan Khamidi dkk (2013), diversifikasi adalah penganekaragaman jenis usaha, bukan hanya produk baru saja, melainkan menyangkut aspek rancangan dan inivasi dari produk. Daft (2010) menyatakan bahwa diversifikasi adalah strategi peralihan ke produk baru dalam rangka memperluas usaha dan menghasilkan barang dan jasa yang berharga.

Solusi untuk meningkatkan pemasaran pada UKM mitra dilakukan dengan cara diversifikasi produk dengan cara penggunaan tepung non terigu agar diperoleh produk yang berbeda dengan produk yang dihasilkan oleh industri bakery lainnya. Tepung yang digunakan sebagai pengganti terigu adalah tepung ubi jalar ungu, tepung ubi jalar oranye dan tepung kasava yang diproduksi oleh IbIKK Program Studi Ilmu dan Teknologi Pangan Fakultas Pertanian Universitas Sumatera Utara yaitu Inovasi Bakery (Gambar 3). Kegiatan ini secara langsung juga akan meningkatkan omzet dari unit usaha yang ada di Universitas Sumatera Utara melalui kerjasama penjualan. Pada kegiatan ini juga dilakukan pelatihan pengolahan tepung non terigu sebagai alternatif bahan baku untuk produk bakery kepada kedua mitra, karena kedua mitra masih belum memiliki pengetahuan dalam hal pengoalahan tepung non terigu.

Produk yang dihasilkan oleh UKM mitra meski sudah dikenal masyarakat sekitar tetapi penampilan masih sederhana dan tidak ditampilkan melalui suatu ruang display yang menarik, sehingga metode yang ditawarkan untuk solusinya adalah memberikan bantuan berupa lemari display produk yang terbuat dari kaca sehingga bisa dilihat secara langsung oleh konsumen. Metode lainnya adalah penyuluhan dan pelatihan memproduksi produk bakery yang sesuai dengan standar kesehatan, mutu yang baik dan citarasa yang menyenangkan serta metode pengemasan yang menarik, bagaimana cara labeling dan pemasaran yang baik. Untuk lebih 
menarik dan memperpanjang umur simpan produk, maka produk-produk yang dihasilkan perlu dilakukan pengemasan.
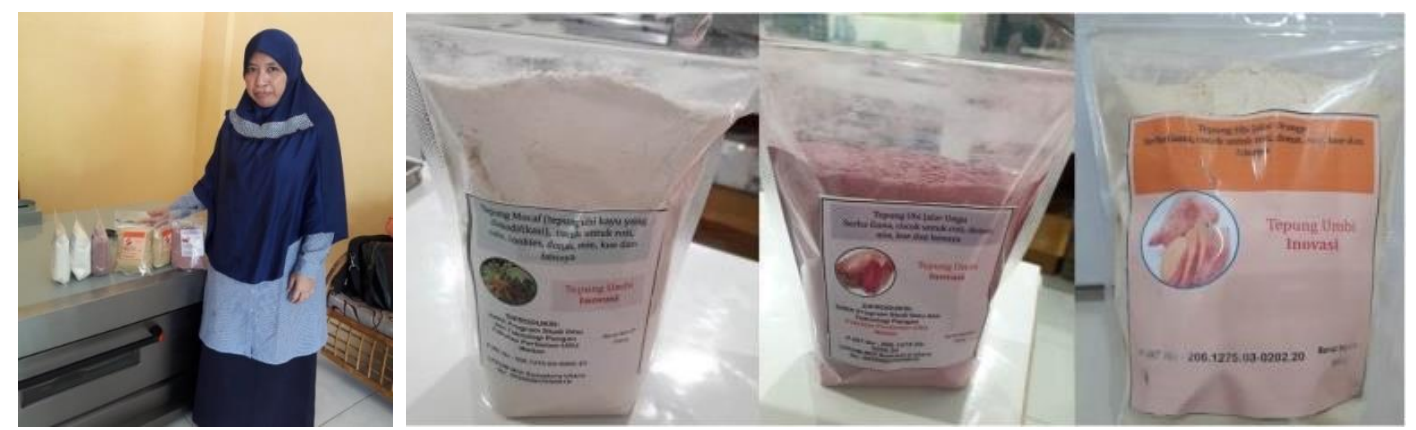

Gambar 3. Sosialisasi penggunaan tepung non terigu sebagai bahan baku pembuatan produk bakery

\section{Partisipasi Mitra Dalam Pelaksanaan Program}

1. Penyediaan tempat dan fasilitas. Tempat yang disediakan oleh oleh mitra adalah rumah sebagai tempat usaha pengoalahan dan pemasaran produk bakery.

2. Menyediakan bahan baku

3. Siap menerima dan mengaplikasikan ipteks yang diberikan tim kegiatan kepada mitra untuk keberlanjutan usahanya.

\section{Evaluasi Pelaksanaan Program dan Keberlanjutan Program}

Evaluasi dilakukan dalam 2 tahap. Evaluasi tahap I dilakukan untuk melihat apakah hasil pelatihan sudah diterapkan oleh mitra UKM dan sesuai dengan standar yang telah ditetapkan sedangkan evaluasi tahap II akan dilakukan dalam bentuk pemantauan apakah mitra UKM sudah ada peningkatan hasil baik produksi, mutu maupun hasil pemasaran dan pendapatan dari hasil kegiatan pengabdian ini. Selama hasilnya masih belum memenuhi target pencapaian produksi maka akan didorong dan diberi pembinaan lebih lanjut guna menstimulasi peserta. Kegiatan pengabdian ini dikategorikan berhasil jika kedua mitra UKM telah melakukan usahanya secara kontinu dan menghasilkan pendapatan yang cukup berarti. Hasil dari kegiatan evaluasi menunjukkan bahwa terjadi peningkatan produktivitas dan pendapatan mitra UKM setelah kegiatan pengabdian dilakukan sebagaimana dapat dilihat pada Tabel 2.

Tabel 2. Produktivitas dan pendapatan mitra sebelum dan setelah kegiatan

\begin{tabular}{|c|c|c|c|}
\hline Mitra & Produktivitas & Sebelum & Setelah \\
\hline \multirow[t]{6}{*}{$\begin{array}{l}\text { Faidah } \\
\text { Catering } \\
\text { Service }\end{array}$} & Jenis Produk & $\begin{array}{l}\text { Katering (Nasi } \\
\text { kotak), Kue kotak } \\
\text { berupa Cake, dan } \\
\text { patiseri (kue basah) }\end{array}$ & $\begin{array}{l}\text { Katering (nasi kotak), } \\
\text { roti, cake, patiseri, dan } \\
\text { cookies }\end{array}$ \\
\hline & Bahan Baku Produk & Terigu & $\begin{array}{l}\text { Terigu, tepung ubi kayu, } \\
\text { tepung ubi jalar }\end{array}$ \\
\hline & Jumlah Karyawan & 2 & 3 \\
\hline & Pemasaran & Langsung & Langsung, media sosial \\
\hline & Omzet/Bulan & Rp.6.000.000,- & Rp.9.000.000,- \\
\hline & Keuntungan/bulan & Rp.3.000.000,- & Rp.6.000.000,- \\
\hline \multirow{2}{*}{$\begin{array}{l}\text { Baraqah Q } \\
\text { Snack, Cake \& } \\
\text { Cookies }\end{array}$} & Jenis Produk & $\begin{array}{l}\text { Cake, snack, dan } \\
\text { cookies }\end{array}$ & $\begin{array}{l}\text { Cake, snack, cookies, } \\
\text { roti }\end{array}$ \\
\hline & Bahan Baku Produk & Terigu & $\begin{array}{l}\text { Terigu, tepung ubi kayu, } \\
\text { tepung ubi jalar }\end{array}$ \\
\hline
\end{tabular}




\begin{tabular}{llll}
\hline Mitra & \multicolumn{1}{c}{ Produktivitas } & \multicolumn{1}{c}{ Sebelum } & \multicolumn{1}{c}{ Setelah } \\
\hline Jumlah Karyawan & 1 orang & 2 orang \\
Pemasaran & $\begin{array}{l}\text { Langsung dan media } \\
\text { sosial }\end{array}$ & $\begin{array}{l}\text { Langsung dan media } \\
\text { sosial }\end{array}$ \\
& Omzet/Bulan & Rp. 3.000.000,- & Rp. 6.000.000,- \\
Keuntungan/bulan & Rp. 2.000.000,- & Rp. 3.000.000,- \\
\hline
\end{tabular}

\section{KESIMPULAN}

Kegiatan pengabdian pada masyakarat dengan berupa diversifikasi produk melalui pemanfaatan tepung umbi-umbian lokal sebagai pengganti terigu pada UKM produk bakery di kota Binjai yang telah dilaksanakan mendapatkan respon yang baik dari kedua mitra yaitu Faidah Catering Service dan Baraqah Q Snack, Cake dan Cookies. Luaran yang diperoleh berupa tersedianya peralatan produksi yang dapat meningkatkan kapasitas produksi dari UKM bakery yaitu oven pemanggang dan mixer adonan, serta bertambahnya pengetahuan mitra tentang diversifikasi produk melalui diversifikasi bahan baku dengan menggunakan tepung umbi-umbian. Mitra telah berhasil memproduksi produk bakery berupa roti, cake, kue-kue basah dan cookies dengan menggunakan tepung ubi jalar dan tepung mocaf. Penggunaan tepung umbi-umbian untuk menggantikan terigu dalam produk bakery dapat dimanfaatkan untuk meningkatkan ketahanan pangan karena hingga saat ini terigu masih merupakan produk impor di Indonesia.

\section{UCAPAN TERIMA KASIH}

Terimakasih diucapkan kepada Lembaga Pengabdian Pada Masyarakat Universitas Sumatera Utara yang telah membiayai kegiatan ini melalui Skim Pengabdian Mono Tahun BPPTN USU Tahun 2018.

\section{Daftar Pustaka}

1. Asosiasi Produsen Tepung Terigu Indonesia. 2012. Permintaan Terigu Terus Meningkat. http://www.aptindo.or.id/index.php?option=com_content\&view=article\&id=111:permintaan-

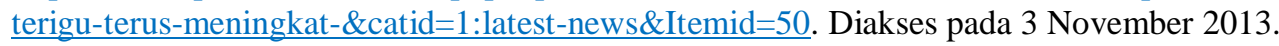

2. Badan Pusat Statistik. 2012. Laporan Bulanan Data Sosial Ekonomi, Edisi 22, Maret 2012. Jakarta: Badan Pusat Statistik.

3. Daft, R.L. 2010. Era Baru Manajemen, Buku 1, Edisi 9. Jakarta: Salemba Empat.

4. Hubeis, M. 2004. Profil Usaha di Indonesia. Makalah Program Studi Industri Kecil Menengah, Sekolah Pascasarjana Institut Pertanian Bogor.

5. Khamidi, S., A. Fauzi, dan I. Suyadi. 2013. Pengaruh Diversifikasi Produk terhadap Penjualan (Studi Kasus pada Perusahaan Konveksi “Faiza Bordir” Bangil - Pasuruan). Jurnal Administrasi Bisnis, 5(2). http://administrasibisnis.studentjournal.ub.ac.id/index.php/jab/article/view/240

6. Kottler, P., dan K.L. Keller. 2009. Manajemen Pemasaran. Terjemahan Bob Sabrab, Edisi 13, Jilid II. Jakarta: Erlangga.

7. Lin, S.D., C.F. Hwang, and C.H. Yeh. 2003. Physical and Sensory Characteristics of Chiffon Cake Prepared with Erythritol as Replacement for Sucrose. Journal of Food Science, 68(6): 2107-2110. https://doi.org/10.1111/j.1365-2621.2003.tb07027.x

8. Nehra, V., E.V. Marietta, and J.A. Murray. 2013. Celiac disease. Encyclopedia of Human Nutrition: 298-306. https://doi.org/10.1016/B978-0-12-375083-9.00046-5

9. Pristiana, U., C. Hidayati, dan B. Wiwoho. 2015. Peningkatan produktivitas dan profitabilitas bagi UKM sentra industri kue bakpia di Gempol Pasuruan Jawa Timur. Jurnal Pengabdian LPPM Untag Surabaya, 1(2): 147-152. 
10. Swaran, S., G.S.S. Chauhan, R. Raghuvanshi, P. Sharma, O.P. Chauhan, and Bajpai. 2003. Replacement of Egg Solids with Whey Protein Concentrate and Optimization of its Levels in Cake Making. Journal of Food Science and Technology, 40: 386-388. 